$\xi=-1$

\title{
Business Model Building and Its Performance in Micro and Small Apparel Industry in Bandung City, Indonesia
}

\author{
Sudrajati Ratnaningtyas ${ }^{1 *}$, Wawan Dhewanto ${ }^{2}$, Bambang Rudito ${ }^{3}$, Eko Agus Prasetio ${ }^{4}$, Gina Karunia Kusumah ${ }^{5}$ \\ ${ }^{1}$ Institut Teknologi Bandung \\ ${ }^{2}$ Institut Teknologi Bandung \\ ${ }^{3}$ Institut Teknologi Bandung \\ ${ }^{4}$ Institut Teknologi Bandung \\ ${ }^{5}$ Institut Teknologi Bandung \\ *Corresponding author E-mail: sudrajati@sbm-itb.ac.id
}

\begin{abstract}
This study aims to determine whether or not the impact of business size on business model building and business performance perceived owner. This research used a quantitative-qualitative approach with Survey Method. The study was conducted in Apparel industry in Bandung City in 2017. The business model used to evaluate is Business Model Canvas (BMC). Chi-Square and Mann-Whitney U tests were used to test the differences between micro business and small business on each of BMC building blocks. The results showed that BMC building blocks between Micro Business and Small Buisness differed on two blocks, ie Channels and Revenue Streams, while the other seven blocks were not different significantly. It can be interpreted that the business model on Micro Businesses is generally slightly different with Small Businesses, or in other words the business strategy is relatively the same. However, the Business Model applied to Small Business with excellence in marketing channels and revenue streams compared to Micro Business, has resulted in a higher level of owner satisfaction on the performance of its business.
\end{abstract}

Keywords: Apparel Industry; Bandung City; Business Model; Business Performance; Micro and Small Business

\section{Introduction}

According to (1) United Nations of Educational, Scientific, and Cultural Organization (UNESCO) has announced the City of Bandung as the City of Design World or City of Design. With the grace of Bandung accepted to join the UNESCO Creative Cities Network (UCCN) network in 2015. Activities related to the design, especially Fashion, graphic design and digital media is a place of economic activity for $56 \%$ of the people of Bandung (2). The creative Economy sector is expected to have a role in the Indonesian economy in the future. The creative economy in Indonesia during 2010-2015 has an average growth of $10.14 \%$ per year, and by 2015 contributes to the National Gross Domestic Product of $7.38 \%$. The three sub-sectors that give the highest contribution are Culinary (41.69\%), Fashion $(18.15 \%)$, and Craft $(15.70 \%)$. Fashion subsector is the largest exporter in 2015, which is 56\% of total exports of Creative Economy Sector (3). However, the growth of GNP of Indonesian Creative Industry in 2010-2015 at constant prices in 2016 shows that the most declining growth is consecutively Fashion, Culinary, and Craft (4).

Research about business in Bandung, Indonesia by (5) explained that there were many potential creative industries in Bandung. Another study in Bandung, Indonesia by (6) used the "Grounding Mobile Policy" and creating creativity in the city using Ad-hoc Network. This network increases the ideas and structure ways in information flows. This fact can enhance creativity in this city. According to (7) the fashion industry in Bandung, Indonesia is growing fastly, especially for micro, small and medium enterprises.

Based on the data (8) in 2015 there are 12.270 units of micro and small enterprises and involving 43,326 workers. Among them are 975 business units in the field of textile and apparel. Apparel industry is a major part of the fashion industry, which needs to be improved so that its growth does not decrease. The firm in business model in fashion is more founded by senior age and highly educated, that is result of research (9). The founder is more make technology to create innovation. The research of (10) shown that the Burberry business model can be increasing performance of fashion business. The Burberry business model is offering partial public share for control the production and distribution, expansion of product, etc. to micro level company. Another business model is proposing by (11) in the model name "An Activity System Perspective". This business model is interdependence system activity. This system activity is concentrated to create value with its partners and share their value. In the future business model is important. According to (12) in the future business model are:1) The new analysis, 2) how to do business, 3) play important role, and 4) how value is created. Another business model in fashion is "Fast Fashion". According (13) the "Fast Fashion" business model is the offer perception of fashionable with affordable price. This business model is specific for fashion business. In 2010 Osterwalder and Pigeur publish the Business Model Canvas (BMC) as a strategic management and lean startup templates for documenting existing or developing new business models.

In Indonesia, Micro Business define as a productive businesses owned by individual and / or individual business entity having net 
assets of IDR 50,000,000 not including land and building of business place or having annual sales result of IDR300,000,000, while Small Business is business a stand-alone productive economy, conducted by an individual or a business entity that is not a subsidiary or not a branch of a company owned, controlled, or a part, directly or indirectly, of a medium-sized or large-scale business with a net worth of more than IDR50,000,000 up to a maximum of IDR500,000,000not including land and building of business premises or having annual sales proceeds of more than IDR300,000,000.00 up to a maximum of IDR2,500,000,000 (14). This paper aims to find out the business strategy applied by micro and small enterprises in the apparel industry in Bandung, which is evaluated by BMC. Also, we need to know whether there are differences in business strategy between the two groups that have different sizes. How is the performance of the strategy implemented by each business group, also is there a difference between micro and small businesses? The business actor requires an evaluation of such matters itself, as well as for its stakeholders, including the Government concerned in developing the business.

\section{Research Method}

\subsection{Research Approach}

This research used a quantitative-qualitative approach with Survey Method. Primary data derived from 15 micro businesses and 15 small businesses in the apparel industry in the city of Bandung. Accidental Sampling technique (15) used in this research with the reason that the population size not clear. There is not enough information about the amount of apparel business among 975 business units in the field of textile and apparel, and how many enterprises are in each micro and small business. Also, the composition and number of business in micro and small enterprises is very dynamic. Within the period from 2015 to 2017 it is possible that the amount has changed. Data collection techniques conducted by in-depth interviews with the owners and employees of the business unit concerned.

\subsection{Data Analysis}

Business Model Canvas and Chi-Square Test used to know the impact of different size on the business model building. The data were analyzed in three steps, as follows:

Step 1: The business strategy of each enterprise in both Micro and Small Business criterion is mapped in Business Model Canvas (BMC) by (16) with nine building blocks

\begin{tabular}{|c|c|c|c|c|}
\hline \multicolumn{5}{|c|}{ BUSINESS MODEL CANVAS } \\
\hline \multirow[t]{2}{*}{$\begin{array}{l}\text { Key } \\
\text { partners }\end{array}$} & $\begin{array}{l}\text { Key ac- } \\
\text { tivities }\end{array}$ & \multirow[t]{2}{*}{$\begin{array}{l}\text { Value } \\
\text { proposition }\end{array}$} & $\begin{array}{l}\text { Customer } \\
\text { relationships }\end{array}$ & \multirow[t]{2}{*}{$\begin{array}{l}\text { Customer } \\
\text { segments }\end{array}$} \\
\hline & $\begin{array}{l}\text { Key re- } \\
\text { sources }\end{array}$ & & Channels & \\
\hline \multicolumn{2}{|c|}{ Cost Structure } & \multicolumn{3}{|c|}{ Revenue streams } \\
\hline
\end{tabular}

Fig. 1. Business Model Canvas: nine business model building blocks (16)

Step 2: Data recapitulation was performed on each block of BMC and carried out for micro business criteria as well as for small businesses. Data is frequency data (nominal data).

Step 3: A partial test was conducted for each block building to know the Business Model difference between micro and small business criteria. For this, we use The Chi-Square Test for two independent samples (17), two-tailed test at $\alpha$ $=0.05$

The data were analyzed in two stages to know the impact of different size on business performance, as follows:

Step 1: In each business criteria, the measurement of the owner's satisfaction level on the profitability of his/her business, measured by ordinal scale using Likert Scale $(5=$ very satisfied, $4=$ satisfied, $3=$ enough, 2 = less satisfied, $1=$ unsatisfied).

Step 2: Mann Whitney U test [17], two-tailed test at $\alpha=0.05$.

\section{Result and Discussion}

\subsection{The Chi-Square Test}

First, Chi-Square test for each of the nine BMC building blocks, then compiled in the recapitulation table. The test results each building block of BMC can be seen in Table 1 .

Table 1. The Chi-Square Test result of nine BMC building blocks

\begin{tabular}{|l|r|r|}
\hline BMC Building Blocks & $\begin{array}{l}\text { Pearson Chi- } \\
\text { Square Value }\end{array}$ & $\begin{array}{l}\text { Asymptotic Signif- } \\
\text { icance } \\
\text { (2-sided) }\end{array}$ \\
\hline 1. Customer Segments & 3.029 & 0.553 \\
\hline 2. Value Proposition & 7.871 & 0.446 \\
\hline 3.Customer Relationships & 5.384 & 0.250 \\
\hline 4. Channels & 6.000 & $0.014^{*}$ \\
\hline 5. Key Activities & 0.465 & 0.792 \\
\hline 6. Key Resources & 0.092 & 0.993 \\
\hline 7. Key Partners & 1.298 & 0.730 \\
\hline 8. Cost Structure & 0.144 & 0.705 \\
\hline 9. Revenue Streams & 5.400 & $0.20^{*}$ \\
\hline
\end{tabular}

*Significant at $\alpha=0.05$

Based on the result of Chi-Square test, results showed that BMC building blocks between Micro Business and Small Buisness differed on two blocks, ie Channels and Revenue Streams, while the other seven blocks were not different significantly. It can be interpreted that the business model on Micro Businesses is generally slightly different with Small Businesses, or in other words the business strategy is relatively the same.

Micro Businesses using single channel are 33\% and others use multi-channels, while Small Businesses $100 \%$ use multi channels. Channels that are mostly used by both business groups are: web sales, partners, stores, and own store. The Wholesaler is only used by some Small Businesses and none of Micro Business uses the channel.

The majority $(86.6 \%)$ of Micro Businesses earn revenue from single stream, whereas in Small Businesses streams almost the same proportion between single with multi streams. In single stream, revenue is obtained only from product sales. In multi streams other than product sales, the company also obtains a usage fee as a result of services such as fashion design, selection and supply of clothes making materials, and other consultations. Revenue streams such as: Assets sale, Subscription fee, Lending / Renting / Leasing, License, Brokerage fees, Advertising are not obtained in this apparel business.

Micro Businesses and Small Businesses target customer segments of the same relative type: Mass markets, Niche Markets, Segmented, Diversified Markets, Multi-sided Markets. Similarly, in terms of Value Proposition Type, among others: Newness, Performances, Customization, Design, Convenience / usability, Price. Another type of Accessibility, Brand / Status, "Getting the Job Done" is only used by a small portion of Small Businesses, while Micro Businesses no one uses it. Customer relationships used are: Personal Assistance, Dedicated Personal Assistance, CoCreation, while Self Services, Automatic Services is not used. Key Activities types used are: Production, Problem Solving, Networking. All businesses use physical and financial resources as key. Human is widely used in the apparel industry, and they use very little intellectual resources. The majority of Micro and Small Businesses have a major partnership in the form of Buyer-seller relationships, Strategic alliance, and Cooperation, while few Joint ventures do it. Cost structure of Cost-driven and Value-driven is used equally in Mico and Small businesses. 
Mann-Whitney $U$ test results show that there is a difference in business performance between Micro Business and Small Business, as in Table 2.

Table 2. The Mann-Whitney U test result of business performance

\begin{tabular}{|l|l|l|}
\hline & Mann-Whitney U & $\begin{array}{l}\text { Asymptotic Significance (2- } \\
\text { sided) }\end{array}$ \\
\hline $\begin{array}{l}\text { Business Per- } \\
\text { formance }\end{array}$ & 61.000 & $0.019^{*}$ \\
\hline
\end{tabular}

*Significant at $\alpha=0.05$

It means that Micro Business owners feel different satisfaction compared with Small Business Owners to profitability of their business. Owners at Micro Business stated the following: 7\% unsatisfied, $20 \%$ less satisfied, $53 \%$ enaough, $20 \%$, and $0 \%$ satisfied. The level of ownership satisfaction on Small Business is better: None stated unsatisfied or less satisfied, $47 \%$ enough, $53 \%$ satisfied, and $0 \%$ very satisfied.

Based on the results of Chi Square Test and Mann-Whitney U Test, it can be seen that there are interesting things, that although only two of the nine BMC building blocks tested different real, while seven others are relatively the same, but produce different satisfaction for the owners. This indicates that many of the few cannels and variations in revenue streams have an impact on the profitability level of the business. Business Model applied to Small Business with excellence in marketing channels and revenue streams compared to Micro Business, has resulted in higher owner satisfaction on the performance of its business.

The implications of this study's findings are the need for more diverse and broader use of marketing channels, as well as the development of revenue sources, particularly Micro Business. In addition, because business performance is actually affected simultaneously by the performance of nine BMC building blocks, the overall blocks need to be improved both in Micro Business and Small Business.

The results of this study also have implications on what should be done by stakeholders of the apparel industry in Bandung. Since BMC Building Blocks in general do not perform satisfactorily, there is still wide opportunity for Academia, and Business, Community, Government, Media to collaborate and work together with Micro Business and Small Business apparels industry in Bandung. Although the Government with Law No. 20 of 2008 has applied different criteria for Micro Business and Small Business, but in fact seven out of nine BMC building blocks are in the same condition. This information needs to be taken into consideration in the preparation of coaching, training, facilitating and development programs of both business groups.

\section{Conclusion}

The BMC building blocks between Micro Business and Small Buisness differed on two blocks, ie Channels and Revenue Streams, while the other seven blocks ie Customer Segments, Value Proposition types, Customer Relationships, Key Activities types, Key Resources, Key Partners, and Cost Structure were not different significantly. It can be interpreted that the business model on Micro Businesses is generally slightly different with Small Businesses, or in other words the business strategy is relatively the same. Channels that are mostly used by both business groups are: web sales, partners, stores, and own store. The Wholesaler is only used by some Small Businesses and none of Micro Business uses the channel. The majority of Micro Businesses earn revenue from single stream, whereas in Small Businesses streams almost the same proportion between single with multi streams. Micro Business owners feel different satisfaction compared with Small Business Owners to profitability of their business. This indicates that many of the few cannels and variations in revenue streams have an impact on the profitability level of the business.

\section{Research Limitation}

The limitation of this study is on sampling technique. The lack is due to the unavailability of information about population size. To anticipate the possibility of abnormal data distribution than in this study used nonparametric statistics test.

\section{Acknowledgment}

The author would like to express gratitude towards all of the parties who supported this research especially to ITB that has been funded this research through the year 2017 P3MI scheme.

\section{References}

[1] Portal Resmi Kota Bandung [Internet]. 2015. Available from: https://portal.bandung.go.id/posts/2015/12/13/Z105/kota-bandungmasuk-dalam-jaringan-unesco-creative-cities-network-uccn

[2] No Title [Internet]. Available from: https://en.unesco.org/creativecities/bandung

[3] Badan Ekonomi Kreatif dan Badan Pusat Statistik. Data Statistik dan Hasil Survei Ekonomi Kreatif [Internet]. 2017. Available from: www.bekraf.go.id/downloadable/pdf_file/170475-data-statistikdan-hasil-survei-ekonomi-kreatif.pdf

[4] BPS-Bekraf. Laporan Penyusunan Tenaga Kerja Sektor Ekonomi Kreatif Tahun 2010-2015. Jakarta; 2016.

[5] Supratman, Sribagjawati; Sudirman, Iman; Sukoyo JS. Identification Characteristics of Potential Creative Industry in Bandung to be Developed through Strategy of Replication. Procedia-Social Behav Sci [Internet]. 2012;65:955-60. Available from:

http://www.sciencedirect.com/science/article/pii/S18770428120521 11

[6] Cohen D. Grounding mobile policies: Ad hoc metworks and the creative city in Bandung, Indonesia. Singap J Trop Geogr [Internet] 2014:36(1):23-37. Available

from: http://onlinelibrary.wiley.com/doi/10.1111/sjtg.12090/full

[7] Siswanto, Joko; Maulida A. ERP module requirements for micro, small and medium enterprise fashion industry in Bandung IEEE Explorer. In: International Conference on Information Technology Systems and Innovation (ICITSI), 2014. IEEE Explorer; 2014.

[8] Dinas Koperasi, Usaha Mikro K dan MKB. Jumlah Unit Usaha dan Tenaga Kerja Industri Kecil dan Mikro di Kota Bandung Bandung, 2017 [Internet]. Bandung; 2017. Available from: http://data.bandung.go.id/dataset/jumlah-unit-usaha-dan-tenagakerja-industri-kecil-dan-mikro-di-kota-bandung-2015\%0A

[9] Bower DJ. Business Model Fashion and the Academic Spinout Firm. R\&D Manag. 2003;33(2):97-106.

[10] Moore, Christopher M.; Birtwistle G. The Burberry Business Model: Creating an International Luxury Fashion Brand. Int J Retail Distrib Manag. 2014;32(8):412-22.

[11] Zott, Christoph; Amit R. Business Model Design: An Activity System Perspective. Long Range Plann. 2010;Pp: 216-226.

[12] Zott, Christoph; Amit, Raphael; Massa L. Business Model: Recent Developments and Future Research. J Manage. 2011;37(4):101942.

[13] Caro, Filipe; Martínez-de-Albéniz V. Fast Fashion: Business Model Overview and Research Opportunities. In: Agrawal, Narendra; Smith SA, editor. Retail Supply Chain Management: Quantitative Models and Empirical Studies [Internet]. 2nd ed. New York: Springer; 2009. p. 237-67. Available from: https://link.springer.com/book/10.1007/978-1-4899-7562-1

[14] Sekretariat Negara. Undang-Undang Republik Indonesia Nomor 20 Tahun 2008 tentang Usaha Mikro, Kecil, dan Menengah. Indonesia; 2008.

[15] Gaspersz V. Teknik Penarikan Contoh Untuk Penelitian Survei. Bandung: Tarsito; 1991.

[16] Osterwalder, Alexander; Pigneur Y. Business Model Generation John Wiley\&Sons, 2010, New Jersey. New Jersey: John Wiley\&Sons; 2010.

[17] Connover. Practical Nonparametric Statistics. 2nd ed. New York: John Wiley\&Sons; 1980. 